University of Nebraska - Lincoln

DigitalCommons@University of Nebraska - Lincoln

Robert Katz Publications

Research Papers in Physics and Astronomy

December 1956

\title{
Correlation between Grades in Engineering Physics and Performance in Engineering Curricula
}

Donald Hoyt

Kansas State College, Manhattan, Kansas

Louis D. Ellsworth

Kansas State College, Manhattan, Kansas

Robert Katz

University of Nebraska-Lincoln, rkatz2@unl.edu

Follow this and additional works at: https://digitalcommons.unl.edu/physicskatz

Part of the Physics Commons

Hoyt, Donald; Ellsworth, Louis D.; and Katz, Robert, "Correlation between Grades in Engineering Physics and Performance in Engineering Curricula" (1956). Robert Katz Publications. 86.

https://digitalcommons.unl.edu/physicskatz/86

This Article is brought to you for free and open access by the Research Papers in Physics and Astronomy at DigitalCommons@University of Nebraska - Lincoln. It has been accepted for inclusion in Robert Katz Publications by an authorized administrator of DigitalCommons@University of Nebraska - Lincoln. 


\title{
Correlation between Grades in Engineering Physics and Performance in Engineering Curricula
}

\author{
Donald Hoyt, Student Counseling Center \\ AND \\ Louis D. Ellsworth AND RoBert Katz, Physics Department, Kansas State College, Manhattan, Kansas

\begin{abstract}
A survey of grades in Engineering Physics I at Kansas State College showed that the inner structure of the course was highly consistent. The correlation coefficient between the average of the first three tests and the final grade was about 0.88 . More significantly, valuable prognostic data could be obtained from the final grade in the course. The correlation coefficient between the Engineering Physics I grade and the final grade point average of students who completed the course was about 0.83 . Only $21 \%$ of the students initially failing the course successfully completed an engineering degree, while about $75 \%$ of the $A, B$, and $C$ students eventually graduated from an engineering curriculum.
\end{abstract}

\section{INTRODUCTION}

$\mathrm{A}^{\mathrm{s}}$ $\mathrm{S}$ the problems associated with tremendous increases in college and university enrollments become acute, educators have greater responsibilities relative to student vocational orientation. Especially for professional training in fields such as engineering which require extensive laboratory equipment, it is important that those students who show reasonable promise of success have priority in the use of limited facilities. The question arises, however, whether there are adequate criteria for predicting reliably success or failure, and if so, what period of time is required to accumulate the information needed. Obviously the ideal solution would be the accumulation of sufficient prognostic data from information available before the student enrolls in college (aptitude and interest tests, high school records, etc). At the other extreme it may be necessary to expose the student to an appreciable part of his curricular requirements and yet not be too certain of his chances of graduating from a given curriculum.

The problem of selection of engineering students has been widely studied. "In researches attempting to predict grades, one rarely finds coefficients of correlation above 0.60 between single predictors and school marks," according to a study by W. L. Layton." Studies at Cornell University in 1932 showed a correlation of 0.84 between a combined grade in analytic geometry

\footnotetext{
${ }^{1}$ Wilbur L. Layton, Selection and Counseling of Students i) Enfincting (University of Minnesota Press, Minrréclie, 1954).
}

and calculus and grade-point average in engineering; and studies at the University of California in 1941 found correlations ranging from 0.87 to 0.61 between several criteria and engineering grade-point averages, the higher correlations being associated with combinations of courses. For example, the correlation between the physics grade and the grade point average in the upper division of engineering was 0.69 , according to the same authority.

Many physics instructors have long assumed that the physics grade was a reliable index of probable success in an engineering curriculum. To them this has justified setting internal standards which often seem higher than those set in other courses, as evidenced by a rather high percentage of failures. The physics department at Kansas State College was interested in obtaining a quantitative study of these relationships.

From the counseling point of view such a study seemed extremely desirable. It is not possible to counsel sophomore engineering students and fail to be impressed by the respect and sometimes fear they have for their engineering physics course. What meaning could the counselor and student ascribe to the engineering physics grade?

\section{THE SCHOOL AND THE COURSE}

The Kansas State College of Agriculture and Applied Science is a land grant institution whose admission requirements consist of graduation from an accredited Kansas high school, or the 
equivalent. While the freshman population is thus essentially unselected, considerable selfselection exists in the school of Engineering. The selection process is furthered by freshman courses, so that the mean ACE score of sophomores enrolled in Engineering Physics $I$ lies at about the seventieth percentile of ACE scores for the total Kansas State freshman class. Translated in terms of the more popularly known terms of "the intelligence quotient," this represents a mean I.Q. of about 120 .

The engineering physics course, of two semesters duration, is conducted on a lecturerecitation-laboratory plan with two hours of lecture, two hours of recitation, and three hours of laboratory each week. According to the traditional pattern quizzes are given in the lecture and course management is essentially the responsibility of the lecturer.

Recitation sections with an initial enrollment of about 30 were taught by staff members (with Ph.D. degrees) while laboratory sections were independently managed by a staff member with help from graduate assistants. During the period from 1949-1951 two different texts were used, namely, Weber, White, and Manning, College Technical Physics, and Mendenhall, Eve, Keys, and Sutton, College Physics, neither of which is currently used as the text for the course. A significant fraction of the staff of the physics department was continuously engaged in teaching the engineering physics course, and grades in the course are a reflection of their joint efforts and evaluations. Finally, grades for the course were evaluated by a 60-20-20 plan, in which 6 one-hour quizzes administered at intervals of 2-3 weeks were weighted $60 \%$, a two hour final exam was weighted $20 \%$, and the laboratory grade was weighted $20 \%$. An attempt was made to obtain uniform grading in the quizzes in that each staff member contributing a problem to a quiz graded that problem for the entire group.

\section{PROCEDURE}

The questions which served as guides in this investigation were:

1. What kinds of students enrolled in Engineering Physics I; to what extent could performance in this course be predicted from available information?
2. What prognostic value did this course possess?

All students enrolled in Engineering Physics I during one or more of five consecutive semesters beginning with the first semester, 1949, were included in the sample which numbered 439 students. Counseling Center and Registrar files were used in determining scholastic aptitude test scores and educational histories for these students. Grades earned in Engineering Physics I were copied from the instructors' grade books. Both letter grades and percentage grades were recorded. Various statistical analyses were performed. All data for the five-semester period were combined in one large sample. All tabulations were made by the Counseling Center without participation of the Physics Department.

\section{RESULTS}

For purposes of analysis the sample was divided into several groups. All initial enrollees in the course were classified in group 1A if they were Kansas State freshman, and in group $1 \mathrm{~B}$ if they were transfer students. Of these, those who withdrew without grade and later repeated the course were called group 2. Those initial enrollees (group 1) who failed and later repeated the course were placed in group 3A if they were Kansas State freshman and in group $3 B$ if they were transfer students. The breakdown into $A$ and $B$ classification was necessitated by the fact that different local norms were maintained for the ACE scores of these groups by the Counseling Center, because of differences in their educational backgrounds at the time of taking the test.

The ACE scores and correlations of various predictive indices with the grade in Engineering Physics I are shown in Table I. This table summarizes available test data pertinent to the first question listed in the previous section.

From Table $I$ it is apparent that, as a group, students registering for Engineering Physics I were substantially higher on a measure of scholastic aptitude than the typical freshman at Kansas State.

Thus, the average score for Group IA students was higher than $75 \%$ of all entering freshmen in 1952 , and the average score for Group 1B students was higher than $67 \%$ of all transfer sophomores entering in 1952 . In fact, the average 
TABLE I. Scholastic aptitudes of students enrolled in Engineering Physics I and predictive indices of their success in the course.

\begin{tabular}{|c|c|c|c|c|c|c|c|c|c|}
\hline \multirow[b]{2}{*}{ Group $^{\mathrm{a}}$} & \multirow[b]{2}{*}{ Number } & \multirow{2}{*}{$\begin{array}{c}\text { Mean } \\
\text { scholastic } \\
\text { aptitude } \\
\text { scores } \\
(\mathrm{ACE}) \mathrm{b}\end{array}$} & \multirow[b]{2}{*}{$\begin{array}{l}\text { Standard } \\
\text { deviation }\end{array}$} & \multirow{2}{*}{$\begin{array}{c}\text { Mean } \\
\text { percentile } \\
\text { score }\end{array}$} & \multicolumn{5}{|c|}{$\begin{array}{c}\text { Correlations between Engineering Physics I grade } \\
\text { and }\end{array}$} \\
\hline & & & & & $\begin{array}{l}\text { ACE } \\
\text { Total }\end{array}$ & $\underset{Q}{A C E}$ & $\underset{L}{\mathrm{ACE}}$ & $\begin{array}{l}\text { Ohio } \\
\text { Psychrometric }\end{array}$ & $\begin{array}{l}\text { Average of first } \\
\mathbf{3} \text { physics tests }\end{array}$ \\
\hline \multirow{5}{*}{$\begin{array}{l}1 \mathrm{~A} \\
1 \mathrm{~B} \\
2 \\
3 \mathrm{~A} \\
3 \mathrm{~B}\end{array}$} & 323 & 112 & 22 & 75 & 0.35 & 0.27 & 0.34 & & 0.85 \\
\hline & 116 & $116^{\circ}$ & $23^{c}$ & $67^{\circ}$ & $0.47^{\circ}$ & $\ldots$ & $\ldots$ & $0.30^{d}$ & 0.90 \\
\hline & 21 & 99 & 18 & 55 & 0.09 & $\ldots$ & $\ldots$ & $\ldots$ & 0.88 \\
\hline & 30 & 97 & 22 & 53 & $\ldots$ & $\ldots$ & $\ldots$ & $\ldots$ & $\ldots$ \\
\hline & 17 & 111 & 23 & 59 & $\ldots$ & $\ldots$ & $\ldots$ & $\ldots$ & $\ldots$ \\
\hline
\end{tabular}

- Group I-all initial enrollees, Group 2-repeaters who withdrew without grade, Group 3-all repeaters who failed the course the first time, subclass A-initial enrollees at Kansas State, subclass B-transfer students.

b 1945 edition of American Council of Education Scholastic Aptitude Test. The $Q$ score is a measure of quantitative ability, while the $L$ score is a measure of linguistic ability.

$0, N=56$ for this variable ( $\mathrm{ACE}$ scores were not available for all transfer students).

d $N=60$ for this variable (scores were not available for all transfer students).

score by Group IA students exceeded the mean score earned by graduates in each of the Engineering and Architecture curriculae except Chemical, Electrical, and Architectural Engineering. Comparable information regarding transfer students was not available.

Only a very limited amount of information is available to the counselor to answer the students questions, "Am I suited for engineering?"; "Can I handle engineering physics?" For the period of this study ACE test scores or the Ohio State Psychological Examination were the only psychometric data available. Three quizzes in Engineering Physics I were regularly graded before the college deadline for dropping a course without grade was reached. Hence the average of these three quizzes was included as a possible prognostic index.

It is clear from Table I that neither the ACE nor the Ohio offered adequate predictive information. Correlations of less than 0.50 are so small that little or no practical counseling use could be made of them in working with individual students.

The outstanding feature of Table I are the three correlations found in the last column. Correlations of such magnitude are very scarce in the general problem of predicting human behavior, and suggest that very valuable prognostic data are available from early performance in the Engineering Physics I course.

The consistency between the first three quizzes and the final letter grade in the course is displayed in more detail in Table II.

Clearly, if a student made an average of less than 60 on his first three quizzes, the probability of his making a final grade of $C$ or better was very small. For that substantial group who average below 50 , none achieved as high as a $C$, and over three-quarters of them failed the course. As is true in most prediction studies, it is more difficult to predict marked success ( $A$ grade) than it is to predict failure.

Once a grade has been made in a course, students, counselors, and advisers are faced with the prospect of interpreting that grade in terms of its implications for the future. It is unusual to know anything at all about what meaning can be attached to a performance in a given course.

In the present study, two methods were used to explore this question. First, the relationship of Engineering Physics I grades to over-all grade-point average for various groups was investigated. Second, the relationship of grades in this course to graduation from Kansas State College was studied.

The results of the first type of analysis are summarized in Table III. The students of the initial sample were redistributed in several categories. A sufficient number of students to

TABLE II. Percent of students earning various grades in Engineering Physics I in relation to early performance in that course."

\begin{tabular}{|c|c|c|c|c|c|c|}
\hline \multirow{2}{*}{$\begin{array}{l}\text { Final } \\
\text { letter } \\
\text { grade }\end{array}$} & \multicolumn{6}{|c|}{ Average of first 3 quizzes } \\
\hline & $\begin{array}{l}90-99 \\
N=36\end{array}$ & $\begin{array}{c}80-89 \\
N=91\end{array}$ & $\begin{array}{c}70-79 \\
N=109\end{array}$ & $\begin{array}{c}60-69 \\
N=94\end{array}$ & $\begin{array}{l}50-59 \\
N=59\end{array}$ & $\begin{array}{c}\text { Below }-50 \\
N=50\end{array}$ \\
\hline \multirow{6}{*}{$\begin{array}{l}A \\
B \\
C \\
D \\
F\end{array}$} & 53 & 9 & 1 & 0 & 0 & 0 \\
\hline & 33 & 56 & 14 & 2 & 2 & $\mathbf{0}$ \\
\hline & 14 & 26 & 48 & 26 & 13 & 0 \\
\hline & 0 & 8 & 33 & 48 & 44 & 24 \\
\hline & 0 & 1 & 4 & 24 & 41 & 76 \\
\hline & $100 \%$ & $100 \%$ & $100 \%$ & $100 \%$ & $100 \%$ & $100 \%$ \\
\hline
\end{tabular}

a Only Groups IA and IB are included in this analysis. 
TABLE III. Relationship of Engineering Physics I grades to total KSC grade-point average.

\begin{tabular}{lrc}
\hline \multicolumn{1}{c}{ Group } & $N$ & Correlation \\
\hline KSC Engineering Students & 259 & 0.84 \\
KSC Arts \& Science Students & 34 & 0.82 \\
Tfr. Engineering Students & 90 & 0.71 \\
\hline
\end{tabular}

warrant correlation studies appeared in only three of these categories. These were students enrolled at KSC in an engineering curriculum, students in an arts and science curriculum (mostly consisting of transfers from engineering), and a third category consisting of transfer students in an engineering curriculum. About one-fourth of these students did not complete a degree, leaving the institution with an average of 80 semester hours. The total grade point average includes the course grade earned in physics. Thus the correlations in Table III may seem spuriously high. However, the contribution of a 5-hour physics grade to total grade point average is negligible since the total number of semester hours averages over 140 for graduates and 80 for nongraduates.

Once again, very good correlations were obtained. Obviously, there was a close relationship between grades in Engineering Physics I and total academic performance. Thus, although grades in this course tended to be lower than those in other courses, the relative ranking remained quite constant. This was true for students who transferred to Arts and Science as well as those who maintained residence in the School of Engineering and Architecture.

In the case of transfer students, the relationship was less marked, but was still considerably higher than that obtained from psychometric data. Perhaps the fact that transfer students typically enrolled in Engineering Physics I during their first registration at Kansas State, and thus had a number of academic adjustment problems to meet, contributed to the lower "meaningfulness" of their performance in this course. If this is true, it might well mean that the most valuable prognostic information from course performance is obtained only after the student has completed enough of his course work to "make the adjustment" to college.

It is of some incidental interest to note that the ACE correlates 0.43 to 0.45 with over-all grade-point average for the groups in Table III. Thus ACE scores could be said to account for about $20 \%$ of the variance in total grade point averages, while the physics grade could account for up to $72 \%$ of this variance. Of course, these are not independent measures, and it seems doubtful that a combination of the two would provide a significantly better prediction than is given by the physics grade alone.

The meaningfulness of physics grades in terms of graduation from Kansas State College is seen in Table IV. For this table the grouping consisted of graduates from Engineering, graduates from some other KSC school, and those who did not graduate.

The fact that $22 \%$ of students earning a grade of $A$ graduated from a nonengineering curriculum might be misleading. A check of the actual curriculum from which these students graduated showed that exactly half (3) of them graduated from an Arts and Science curriculum which required Engineering Physics I. One $B$ student and two $D$ students had similar histories.

From Table IV it is apparent that about onehalf of the registrants in physics graduated from a physics-required curriculum; about one-sixth graduated from some other curriculum; and about one-third did not graduate.

There is an obvious relationship between physics grades and these summary figures. If a student earned a grade of $C$ or higher in the course, the chances of his graduating from Kansas State College were about 85 in 100. The chances of his graduating in an engineering curriculum were roughly 75 in 100 . For the student who failed the course, these figures

TABLE IV. Relationship of Engineering Physics grades to graduation for Kansas State College.

\begin{tabular}{|c|c|c|c|c|c|c|}
\hline $\begin{array}{c}\text { Grade in } \\
\text { Engt. } \\
\text { Physics }\end{array}$ & \multicolumn{2}{|c|}{$\begin{array}{l}\text { Graduated } \\
\text { from } \\
\text { Engineering } \\
\text { No. \%ः }\end{array}$} & \multicolumn{2}{|c|}{$\begin{array}{c}\text { Graduated } \\
\text { from } \\
\text { some other } \\
\text { KSC school } \\
\text { No. \%" }\end{array}$} & \multicolumn{2}{|c|}{$\begin{array}{c}\text { Did not } \\
\text { graduate } \\
\text { No. } \%\end{array}$} \\
\hline $\begin{array}{l}A \\
B \\
C \\
D \\
F \\
W d\end{array}$ & $\begin{array}{r}19 \\
66 \\
82 \\
63 \\
19 \\
3\end{array}$ & $\begin{array}{r}68 \\
81 \\
73 \\
50 \\
21 \\
7\end{array}$ & $\begin{array}{r}6 \\
4 \\
14 \\
24 \\
18 \\
13\end{array}$ & $\begin{array}{r}22 \\
5 \\
12 \\
19 \\
20 \\
30\end{array}$ & $\begin{array}{r}3 \\
11 \\
17 \\
39 \\
54 \\
27\end{array}$ & $\begin{array}{l}10 \\
14 \\
15 \\
31 \\
59 \\
63\end{array}$ \\
\hline Total & 252 & 52 & 79 & 16 & 151 & 32 \\
\hline
\end{tabular}

- This column indicates the percent of those receiving a given letter grade in Engineering Physics I who graduated from the school of
engineering, etc., e.g., all $A^{\prime}$ 's sum to $100 \%$. 
dropped to 41 in 100 and 21 in 100 , respectively. When we consider the large number of reasons why students discontinue academic training, other than for low grades (lack of finances, illness, military service, jobs, etc.) this relationship appears even more remarkable.

Students who fail the course and then repeated it constitute a group about whom many questions have been raised. It was therefore particularly interesting to study their subsequent academic careers. A special summary of the graduation records of those students is provided in Table $\mathrm{V}$.

Slightly over $\frac{1}{3}$ of these students were successful in gaining a degree from an engineering curriculum, while nearly $\frac{1}{2}$ of them did not graduate from any Kansas State curriculum. Only for those students who obtained a $B$ (or presumably an $A$-no $A$ students were found) were the odds of graduating from an engineering curriculum better than 50-50.

As noted previously, grades in Engineering Physics I were somewhat lower than grades in other courses. This is reflected in Table VI.

Implied in this finding is the suggestion that the standards of the course are more demanding than those of most other courses. Whether the grades are unrealistically low, in the sense of "washing out" potentially competent engineers, remains an important, but unanswered question.

\section{SUMMARY AND CONCLUSIONS}

The following conclusions seem warranted:

1. Students who registered for Engineering Physics I scored substantially higher on measures of academic aptitude than does the average

TABLE V. Academic progress of students who repeated Engineering Physics I after one failure.

\begin{tabular}{|c|c|c|c|c|c|c|}
\hline \multirow{2}{*}{$\begin{array}{c}\begin{array}{c}\text { Engr. } \\
\text { Physics } \\
\text { Grade }\end{array} \\
A \\
B \\
C \\
D \\
F\end{array}$} & \multicolumn{2}{|c|}{$\begin{array}{l}\text { Graduated } \\
\text { from } \\
\text { Engineering } \\
\text { No. } \%\end{array}$} & \multicolumn{2}{|c|}{$\begin{array}{c}\text { Graduated } \\
\text { from } \\
\text { some other } \\
\text { KSC school } \\
\text { No. \% } \%^{\mathrm{a}}\end{array}$} & \multicolumn{2}{|c|}{$\begin{array}{r}\text { Did not } \\
\text { graduate } \\
\text { No. } \%\end{array}$} \\
\hline & $\begin{array}{l}0 \\
4 \\
7 \\
6 \\
0\end{array}$ & $\begin{array}{r}0 \\
66 \\
44 \\
33 \\
0\end{array}$ & $\begin{array}{l}0 \\
1 \\
4 \\
2 \\
2\end{array}$ & $\begin{array}{r}0 \\
17 \\
25 \\
11 \\
29\end{array}$ & $\begin{array}{r}0 \\
1 \\
5 \\
10 \\
5\end{array}$ & $\begin{array}{r}0 \\
17 \\
31 \\
56 \\
71\end{array}$ \\
\hline Total & 17 & 36 & 9 & 19 & 21 & 45 \\
\hline
\end{tabular}

- This column indicates the percent of those receiving a given letter grade in Engineering Physics 1 who graduated from the school of engineering, etc., e.g., all $B$ 's sum to $100 \%$.
Table VI. Comparison of Engineering Physics I gradepoint average with over-all grade-point average for various groups.

\begin{tabular}{lrrc}
\hline \multicolumn{1}{c}{ Grade } & \multicolumn{1}{c}{$N$} & $\begin{array}{c}\text { Engr. Physics I } \\
\text { Averages }\end{array}$ & $\begin{array}{c}\text { Over-all Grade } \\
\text { Point Average }\end{array}$ \\
\hline Engr. Grads. & 250 & 1.03 & 1.60 \\
Engr. Nongrads. & 99 & -0.05 & 0.77 \\
Other Grads. & 77 & 0.38 & 1.47 \\
Other Nongrads. & 13 & -0.54 & 0.78 \\
\multicolumn{1}{c}{ Total } & 439 & 0.57 & 1.36 \\
\hline
\end{tabular}

$A=3, B=2, C=1, D=0, F=-1$.

freshman student. In fact, the average score for these students was roughly equivalent to that made by graduates from various engineering curricula when those graduates were freshmen.

2. Available tests of scholastic aptitude were inadequate predictors of achievement in physics, or of achievement in engineering.

3. Outstanding predictions of final physics grades could be made on the basis of the first three quizzes in the course. This finding is important, since students may withdraw without a grade after the first three tests have been scored.

4. Engineering Physics I grades bore a close relationship to over-all grade-point average. The correlation was around 0.83 for Kansas State students, and about 0.70 for transfer students.

5. Achievement in Engineering Physics I was also closely related to graduation. Grades of $C$ or better indicated a strong likelihood of eventual graduation, usually from an engineering curriculum. Failing grades carried strong negative implications for graduation, particularly from engineering.

6. About one-half of the students who repeated the course after once having failed it did not graduate from any curriculum. About onethird of these students did eventually graduate from an engineering curriculum.

7. Grades earned in Engineering Physics I were considerably lower than the over-all grade point averages of students in this study. The discrepancy was less for students who maintain registration in an engineering curriculum than for those who change to other curricula and was less for graduates than nongraduates.

The course in Engineering Physics at Kansas State College follows a traditional pattern. The 
academic origin of instructors within the course is quite diverse and represents something of an amalgam of American institutions. It seems reasonable that similar findings would be obtained by comparable physics courses elsewhere.

\section{ACKNOWLEDGMENTS}

The clerical and computational assistance of Roberta Clapp, Audrey Patterson, C. E. Kennedy, and Charles Bates of the Counseling Center is gratefully acknowledged. 